\title{
Tools for Monitoring Energy Efficiency of Municipalities' Housing and Utilities Sector and Budget Sector (the Case of the Volgograd Region)
}

\author{
Lyudmila Yuryevna Bogachkova \\ Institute of Regional Economy and Management \\ Volgograd State University \\ Volgograd, Russia \\ bogachkova@volsu.ru
}

\author{
Yuliya Vladimirovna Zaytseva \\ Institute of Regional Economy and Management \\ Volgograd State University \\ Volgograd, Russia \\ zaytseva_julia@volsu.ru
}

\author{
Nadezhda Yuryevna Usacheva \\ Institute of Regional Economy and Management \\ Volgograd State University \\ Volgograd, Russia \\ n.y.usacheva@ volsu.ru
}

\begin{abstract}
The efficiency of using energy resources is a prerequisite for ensuring competitive, sustainable and safe economic development at the federal, regional and subregional levels. Increasing the energy efficiency of the national economy is a priority area of the state economic policy of Russia. However, the national system of information and analytical support of energy efficiency policy is still at the initial stage of development. The development of tools for analyzing the performance of this policy is an important national economic task and an urgent scientific problem.
\end{abstract}

The present paper outlines the condition and prospects of developing the tools for monitoring the performance of energy efficiency policy at the regional and subregional levels. The annual rankings of energy efficiency of the Volgograd region's municipalities are drawn up on the basis of the Volgogradstat data on energy consumption indicators for 2012-2016 in the budget sector and in the housing fund. We analyze the dynamics of relative energy efficiency levels, and reveal the most advanced and the most lagging municipalities.

We argue that ensuring the completeness, transparency and verifiability of data on the introduction of advanced energyefficient technologies to housing and utilities sector and to the budget sector requires the inclusion of these data in the list of indicators used in the ranking of municipalities.

Keywords-energy efficiency policy, regional economy, energy consumption in municipalities, housing and utilities sector and budget sector, ranking of municipalities' energy efficiency

\section{INTRODUCTION}

In modern Russia, as in most countries of the world, the efficiency of using energy resources is considered as a necessary condition for ensuring competitive, sustainable and safe economic development at the national, regional and

The research was funded by the Russian Fund for Fundamental Research and Administration of the Volgograd region, project 17-12-34041 "Development of tools for decision-making on estimating the effectiveness of energy saving policy and increasing energy efficiency of the region". subregional levels. Energy efficiency (EE) is the optimal use of fuel and energy resources in all sectors of the national economy at the achieved level of technological progress and taking into account the requirements for environmental protection [1]. Insufficient EE and excess energy intensity of individual production processes entail the increase in production unit costs and, consequently, the reduced competitiveness of the final product. Wasteful energy consumption in the nonproduction sphere has a negative impact on living standards of the population, since it leads to increased spending on energy consumption in household use and to deterioration of living conditions. Therefore, energy saving (ES) and the improvement of EE of the national economy is one of the priorities of the state economic policy of most countries.

Today, long-term state programs of ES and EE improvement have been developed and implemented at the federal, regional and subregional levels in Russia. The performance of these programs depends on the organization of appropriate monitoring. At the same time, the national EE monitoring system is still at the development stage. Therefore, the development of tools for evaluating the performance of EE policy, especially at the regional and municipal levels, is an important national economic task and an urgent scientific problem [2].

Starting from 2014, the Ministry of Energy of the Russian Federation, with the participation of experts from the National Research University Higher School of Economics, has monitored the performance of the state EE policy at the sectoral and regional levels. The research results are disclosed in the annual State report on the condition of ES and EE improvement in the Russian Federation (hereinafter the State report) [3-5]. The monitoring is based on the data from the following sources: official statistical reports of 
Rosstat (Russian State Statistics Service); special forms of information for the preparation of the State Report; information of the state information system (GIS) "Energy Efficiency"; other information provided by the subjects of the Russian Federation. However, the data collected and provided by the regions are characterized by incompleteness and unreliability, particularly the information from municipalities' representatives responsible for ES and EE improvement. The data calculated by Rosstat on the basis of annual federal statistical observations are considered to be the most complete and reliable [4]. At the subregional level, the analysis of energy efficiency is not carried out in State reports.

The analysis of the State reports shows that the Volgograd region ranks average among other regions of the Russian Federation by the indicator of performance of the state policy on ES and EE improvement. In the short term, the Volgograd region has to work out and implement requirements for $\mathrm{EE}$ in construction and total building renovation; to draw up annual regional reports on the condition of ES and EE improvement in the region using the example of State-level reports; to develop a plan of regional activities in the sphere of ES and EE improvement for the period from 2018 to 2025 [6]. Thus, increasing the performance of the EE policy of the subject of the Russian Federation foregrounds the problem of conducting a comparative analysis of the indicators of energy consumption in municipalities at the regional level, similarly to the comparison of regional indicators at the federal level. First of all, it is expedient to analyze the most promising, from the viewpoint of ES and EE improvement, sectors of the economy.

In terms of energy saving, the most promising sectors include the housing and utilities sector, the operation, construction and building renovation in the public and municipal sector (the budget sector). According to experts' estimates, more than $20 \%$ of the total energy saving potential of Russia accrue to the housing and utilities sector and the budget sector. Multi-apartment houses (MAHs) consume a significant share of the total amount of energy produced in the country: up to $52 \%$ of thermal energy, up to $30 \%$ of electricity [5]. The primary task for realizing this potential of ES and EE improvement in the housing and utilities sector and in the budget sector consists in the correct accounting and the extensive analysis of energy consumption.

The purpose of the present research is to develop the tools for evaluating the performance of energy efficiency policy at the subregional level using the example of ranking the municipalities in the Volgograd region by the indicator of energy consumption efficiency in the housing and utilities sector and in the budget sector.

\section{MATERIALS AND METHODS (MODEL)}

In 2014, the Ministry of Energy of the Russian Federation outlined the list and methods for calculating the target indicators of ES and EE improvement for the regions (in general) and for their municipalities [7]. A total of 31 indicators for the regions and 27 for the municipalities are chosen as the objects of accounting and analysis. In practice, however, a much smaller number of municipal indicators are available at the Federal State Statistics Service. For example, the Territorial Body of State Statistics for the Volgograd region (Volgogradstat) calculates and discloses the data on only 10 indicators in the certificates of municipalities, and all of them characterize the efficiency of energy consumption in the housing and utilities sector and in the budget sector.

\section{A. Starting data}

Table 1 shows the specific indicators of municipalities' energy consumption (energy consumption per person, per unit area or per unit volume) provided by Volgogradstat for 2012-2016. A number of municipalities lack the data on some indicators, and this indicates a low quality of accounting and control of energy consumption. According to the indicators presented in Table 1 , we can compile and analyze the integrated ranking of regional municipalities' EE in the housing and utilities sector and in the budget sector, using the methods described below.

B. Methodology for ranking the municipalities of the Volgograd region by the indicators of energy efficiency in housing and utilities sector and in the budget sector (per year)

Agreed notation: $1 \leq i \leq 10$ - number of specific EE index; $1 \leq j \leq 39$ - identifier of municipality (municipalities are divided into municipal districts and municipal cities/towns); $P_{i}-i$-th specific index; $P_{i j}-i$-th specific index for $j$-th district; $P_{i \max }-$ maximum value of the $i$-th specific index among all municipalities.

TABLE 1. SPECIFIC INDICATORS OF ENERGY CONSUMPTION EFFICIENCY IN THE HOUSING AND UTILITIES SECTOR AND IN THE BUDGET SECTOR OF MUNICIPALITIES OF THE VOLGOGRAD REGION (2012-2016)

\begin{tabular}{|c|c|c|}
\hline \multicolumn{3}{|r|}{ EE indicators for multi-apartment houses $(\mathrm{MAH})^{\mathrm{a}}$} \\
\hline 1. & $\mathrm{P}_{1}$ & Electricity consumption in MAH (KW/h per 1 person) \\
\hline 2. & $P_{2}$ & Thermal energy consumption in MAH $\left(\mathrm{Gcal} / 1 \mathrm{~m}^{2}\right)$ \\
\hline 3. & $P_{3}$ & Hot water consumption in $\mathrm{MAH}\left(\mathrm{M}^{3}\right.$ per 1 person $)$ \\
\hline 4. & $P_{4}$ & Cold water consumption in MAH $\left(\mathrm{M}^{3}\right.$ per 1 person $)$ \\
\hline 5. & $P_{5}$ & Natural gas consumption in $\mathrm{MAH}\left(\mathrm{M}^{3}\right.$ per 1 person $)$ \\
\hline \multicolumn{3}{|r|}{ EE indicators for municipal budget institutions (MBI } \\
\hline 6. & $P_{6}$ & Electricity consumption in $\mathrm{MBI}(\mathrm{KW} / \mathrm{h}$ per 1 person $)$ \\
\hline 7. & $P_{7}$ & Thermal energy consumption in $\mathrm{MBI}\left(\mathrm{Gcal} / 1 \mathrm{~m}^{2}\right)$ \\
\hline 8. & $P_{8}$ & Hot water consumption in $\mathrm{MBI}\left(\mathrm{M}^{3}\right.$ per 1 person $)$ \\
\hline 9. & $P_{9}$ & Cold water consumption in $\mathrm{MBI}\left(\mathrm{M}^{3}\right.$ per 1 person $)$ \\
\hline 10 & $P_{10}$ & Natural gas consumption in MBI ( $\mathrm{M}^{3}$ per 1 person $)$ \\
\hline
\end{tabular}

If there is no starting value of the indicator, let us assume that $P_{i j}=0$.

Let us denote the specific ranking estimate of the $j$-th municipality by the $i$-th index $\omega_{i j}$ and determine it using a formula: 


$$
\omega_{i j}=\left[\begin{array}{l}
\frac{P_{i j}}{P_{\text {max }}}, \text { if } P_{i j} \neq 0 ; \\
100, \quad \text { if } P_{i j}=0 .
\end{array}\right.
$$

Thus, $\omega_{i j}=100$ when there is no starting data on the specific indicator. In the specific ranking by the analyzed indicator, this technique allows for placing the given municipality at the end of the list due to insufficient information logistics of EE policy; in the integrated ranking by the integral part of ranking estimate, the technique allows for determining the number of indicators, which are not monitored by the $j$-th municipality.

According to formula (1), we get the condition: if $\omega_{i j}$ $\neq 100$, then $0 \leq \omega_{i j} \leq 1$. The closer the value $\omega_{i j}$ to zero, the less the energy capacity of the given municipality with $j$ identifier by the $i$-th index, and the closer $\omega_{i j}$ to 1 , the higher the energy capacity of the given municipality by the $i$-th index. The less the energy capacity is, the higher the energy efficiency is.

We obtain the integrated ranking estimate of the $j$-th municipality by all 10 specific indicators of energy efficiency using the equation:

$$
R_{j}=\frac{\sum_{i=1}^{10} \omega_{i j}}{10} .
$$

Let $\left[R_{j}\right]$ be an integral part of the value of variable $R_{j}$, calculated by (2), and $n_{j}$ be a number of specific indicators, which are not monitored by the $j$-th municipality. We observe the following correlation:

$$
n_{j}=\left[R_{j}\right] / 10
$$

Fractional part $180=R_{j}-\left[R_{j}\right]$ is an integral ranking estimate of the $j$-th municipality by indicators having starting data. The less the value of variable 80 is, the more energy efficient the municipality is.

Let us rate the municipalities by $R_{j}$ increase, and we get integrated ranking. Let $N_{j}$ be an order number of municipality with $j$ identifier in the ranking.

Municipalities with $\left[R_{j}\right] \neq 0$, i.e. with no starting data on $n_{j}$ indicators, are placed at the end of the ranking list. We determine the number of indicators with lacking data for them using (3).

\section{RESULTS AND DISCUSSION}

\section{A. Results}

The results of applying the described methodology are given in Table 2, in which the municipalities of the Volgograd region are ranked according to their positions in the 2016 ranking.
TABLE 2. INTEGRATED RANKINGS OF ENERGY EFFICIENCY OF THE MUNICIPALITIES OF THE VOLGOGRAD REGION BY THE

\begin{tabular}{|c|c|c|c|c|c|c|c|c|c|c|}
\hline \multirow{2}{*}{ Municipality } & \multicolumn{2}{|c|}{2012} & \multicolumn{2}{|c|}{2013} & \multicolumn{2}{|c|}{2014} & \multicolumn{2}{|c|}{2015} & \multicolumn{2}{|c|}{2016} \\
\hline & $N$ & $n$ & $N$ & $n$ & $N$ & $n$ & $N$ & $n$ & $N$ & $n$ \\
\hline Ilovlinsky District & 1 & 0 & 1 & 0 & 1 & 0 & 1 & 0 & 1 & 0 \\
\hline Zhimovsky District & 17 & 1 & 17 & 1 & 5 & 0 & 6 & 0 & 2 & 0 \\
\hline $\begin{array}{l}\text { Gorodishchensky } \\
\text { District }\end{array}$ & 2 & 0 & 2 & 0 & 4 & 0 & 4 & 0 & 3 & 0 \\
\hline $\begin{array}{l}\text { Sredneakhtubinsky } \\
\text { District }\end{array}$ & 4 & 0 & 3 & 0 & 2 & 0 & 2 & 0 & 4 & 0 \\
\hline Kamyshin Town & 8 & 0 & 7 & 0 & 8 & 0 & 7 & 0 & 5 & 0 \\
\hline Mikhaylovka Town & 28 & 2 & 28 & 2 & 7 & 0 & 9 & 0 & 6 & 0 \\
\hline Volgograd City & 6 & 0 & 5 & 0 & 6 & 0 & 10 & 0 & 7 & 0 \\
\hline Volzhsky City & 3 & 0 & 4 & 0 & 3 & 0 & 3 & 0 & 8 & 0 \\
\hline Kotovsky District & 9 & 0 & 9 & 0 & 11 & 0 & 5 & 0 & 9 & 0 \\
\hline Leninsky District & 16 & 1 & 15 & 1 & 18 & 1 & 11 & 0 & 10 & 0 \\
\hline Frolovo Town & 5 & 0 & 6 & 0 & 9 & 0 & 8 & 0 & 11 & 0 \\
\hline Uryupinsk Town & 10 & 0 & 10 & 0 & 12 & 0 & 12 & 0 & 12 & 0 \\
\hline Svetloyarsky District & 7 & 0 & 8 & 0 & 10 & 0 & 13 & 0 & 13 & 0 \\
\hline Kalachevsky District & 18 & 1 & 18 & 1 & 13 & 0 & 14 & 0 & 14 & 0 \\
\hline Nikolayevsky District & 12 & 1 & 12 & 1 & 15 & 1 & 17 & 1 & 15 & 1 \\
\hline Kletsky District & 11 & 1 & 14 & 1 & 17 & 1 & 16 & 1 & 16 & 1 \\
\hline Kamyshinsky District & 14 & 1 & 11 & 1 & 14 & 1 & 15 & 1 & 17 & 1 \\
\hline Frolovsky District & 13 & 1 & 16 & 1 & 19 & 1 & 19 & 1 & 18 & 1 \\
\hline Kotelnikovsky District & 24 & 2 & 23 & 2 & 23 & 2 & 24 & 2 & 19 & 1 \\
\hline Dubovsky District & 15 & 1 & 13 & 1 & 16 & 1 & 18 & 1 & 20 & 1 \\
\hline Alekseevsky District & 20 & 2 & 19 & 2 & 20 & 2 & 20 & 2 & 21 & 2 \\
\hline Pallasovsky District & 23 & 2 & 20 & 2 & 21 & 2 & 21 & 2 & 22 & 2 \\
\hline Rudnyansky District & 29 & 2 & 29 & 2 & 29 & 2 & 22 & 2 & 23 & 2 \\
\hline Oktyabrsky District & 21 & 2 & 21 & 2 & 22 & 2 & 23 & 2 & 24 & 2 \\
\hline Kikvidzensky District & 30 & 2 & 27 & 2 & 26 & 2 & 27 & 2 & 25 & 2 \\
\hline Surovikinsky District & 19 & 2 & 30 & 2 & 30 & 2 & 25 & 2 & 26 & 2 \\
\hline Novoanninsky District & 26 & 2 & 25 & 2 & 25 & 2 & 30 & 2 & 27 & 2 \\
\hline Kumylzhensky District & 27 & 2 & 26 & 2 & 27 & 2 & 26 & 2 & 28 & 2 \\
\hline $\begin{array}{l}\text { Serafimovichsky } \\
\text { District }\end{array}$ & 31 & 2 & 32 & 2 & 32 & 2 & 29 & 2 & 29 & 2 \\
\hline Elansky District & 32 & 2 & 31 & 2 & 31 & 2 & 32 & 2 & 30 & 2 \\
\hline Danilovsky District & 22 & 2 & 24 & 2 & 24 & 2 & 31 & 2 & 31 & 2 \\
\hline $\begin{array}{l}\text { Novonikolaevsky } \\
\text { District }\end{array}$ & 25 & 2 & 22 & 2 & 28 & 2 & 28 & 2 & 32 & 2 \\
\hline Nekhaevsky District & 33 & 2 & 33 & 2 & 33 & 2 & 33 & 2 & 33 & 2 \\
\hline Staropoltavsky District & 39 & 5 & 38 & 5 & 35 & 3 & 34 & 3 & 34 & 3 \\
\hline Chernyshkovsky & 34 & 3 & 34 & 3 & 36 & 3 & 35 & 3 & 35 & 3 \\
\hline Uryupinsky District & 35 & 3 & 35 & 3 & 37 & 3 & 36 & 3 & 36 & 3 \\
\hline Olkhovsky District & 36 & 4 & 37 & 4 & 34 & 3 & 37 & 4 & 37 & 4 \\
\hline Bykovsky District & 37 & 4 & 36 & 4 & 38 & 4 & 38 & 4 & 38 & 4 \\
\hline Mikhaylovsky District & 38 & 4 & 39 & 10 & 39 & 10 & 39 & 10 & 39 & 10 \\
\hline
\end{tabular}
INDICATORS OF ENERGY CONSUMPTION IN THE HOUSING AND UTILITIES SECTOR AND IN THE BUDGET SECTOR

Compiled on the basis of calculations. Agreed notation: $N$ - place in the ranking; $n$ - number of indicators, which are not monitored by the municipalities. The municipalities are indexed in accordance with their places in the ranking of 2016

As can be seen from Table 2, the Ilovlinsky Municipal District (MD) had been the most energy efficient during the whole period under consideration. The Zhirnovsky, Gorodishchensky and Sredneakhtubinsky MDs showed stable good results. The Zhirnovsky MD and Mikhaylovka Town had leapt significantly for four years and improved their performance. The Uryupinsky, Chernyshkovsky, Olkhovsky and Bykovsky MDs, on the contrary, had consistently 
demonstrated poor results. The Mikhaylovsky MD, where the account of energy consumption indicators is not carried out (there are no data on this MD), turned to be the worst one.

Applying the methodology for compiling annual rankings over a number of years makes it possible to trace the dynamics of the relative energy efficiency of municipalities, according to which the performance of the EE policy can be judged. The identification of the most advanced and the most lagging municipalities is necessary to improve the management of the region's ES and EE improvement in general.

\section{B. Discussion}

The proposed methodology allows for compiling the energy efficiency ranking of the Volgograd region's municipalities on the basis of available indicators of energy consumption in the housing and utilities sector and in the budget sector. However, some data on energy consumption necessary for the EE official monitoring, are not available for analysis.

The certificates of the Volgograd region's municipalities, disclosed by Rosstat, do not contain information on such indicators as equipping the MAHs and MBIs with energy consumption metering devices; specific electricity consumption for communal needs in MAHs $\left(\mathrm{kWh} / \mathrm{m}^{2}\right)$; equipping the MAHs with building-level heat meters; the ratioof the costs of electricity consumption for communal needs and the thermal energy consumption in MAHs to the total area of the MAHs $\left(\mathrm{kgoe} / \mathrm{m}^{2}\right)$; specific costs of electrical and thermal energy per $1 \mathrm{~m}^{2}$ in the budgetary institutions differentiated with respect to health care and education. The proposed methodology can be easily generalized so as to remain effective in case of expanding the list of data. Besides, its application will lead to a more accurate estimation of municipalities' energy efficiency.

It would make sense to take into account the indicators characterizing the level of introduction of advanced energyefficient technologies in order to improve the accuracy of ranking estimates in the future. These indicators include the share of buildings with a relatively high level of energy efficiency (above D level); the share of LEDs in outside and inside lighting of budget sector organizations; the share of buildings equipped with individual heat points with automatic climate control among all buildings, which have been totally renovated since 2012 to the value of, at least, 5 million rubles (in the budget sector) [5]. The difficulty of using the mentioned indicators in municipalities ranking consists in the lack of sufficient data and reliability, as well as in their unavailability to independent researchers. Actually, it is not the Rosstat who accumulates the data on the introduction of advanced energy-efficient technologies. They are calculated on the basis of energy declarations that are completed by state and municipal institutions and registered in the state information system (GIS) 'Energy Efficiency'. The share of state and municipal institutions that completed the energy declaration for 2016 in the Volgograd region, amounted to $84 \%$. On the one hand, this figure indicates incompleteness of data (less than 100\%), and on the other hand, it significantly exceeds the average Russian level, which makes $77 \%$ [5]. In case of ensuring the completeness, transparency and verifiability of information on the introduction of advanced energy-efficient technologies, these indicators should be included in the list of specific indicators that are taken into account when ranking municipalities in the housing and utilities sector and in the budget sector.

\section{CONCLUSION}

The paper outlines the methodology for integrated ranking estimation of municipalities' energy consumption efficiency in the housing and utilities sector and in the budget sector. The proposed methods are implemented using the available data of the Volgograd region for 2012-2016. Compilation and comparative analysis of annual rankings over a number of years allows for controlling the dynamics of relative energy efficiency levels of municipalities, which reflects the performance of the EE policy. The identification of the most advanced and the most lagging municipalities on the basis of the ranking estimates contributes to enhancing the management of ES and EE improvement of the region in general. As far as the system of accounting for energy efficiency of the Russian economy develops, it is advisable to supplement the list of specific indicators with missing data on energy consumption in the housing and utilities sector and on the use of advanced energy efficient technologies in the budget sector. This will upgrades the accuracy of ES and EE estimation at the subregional level.

\section{References}

[1] V.V. Bushuev, A.M. Belogoryev, O.Yu. Apolonsky, E.A. Borgolova, V.V. Timatkov, Sustainable development of oil and gas companies: from theory to practice. Moscow: Information Center 'Energia', 2012. 88

<https://istina.msu.ru/media/publications/book/afa/3a7/24577443/Ustoj chivoe_razviie_neftegazovyih_kompanij_-_ot_teorii_k_praktike.pdf $>$.

[2] L.Yu. Bogachkova, Sh.G. Khurshudyan, "Development of tools for analyzing the effectiveness of energy efficiency policies in the regions of Russia: problems and solutions," Internet science, vol. 3, pp. 36-46, 2017.

<https://internetnauka.ru/index.php/journal/article/view/569/812>.

[3] Ministry of Energy of the Russian Federation (2015), State report on energy saving and energy efficiency in the Russian Federation in 2014, <https://minenergo.gov.ru/node/5197>.

[4] Ministry of Energy of the Russian Federation (2016), State report on energy saving and energy efficiency in the Russian Federation in 2015, <https://minenergo.gov.ru/node/5197>.

[5] Ministry of Energy of the Russian Federation (2017), State report on energy saving and energy efficiency in the Russian Federation in 2016, <https://minenergo.gov.ru/node/5197>.

[6] L.Yu. Bogachkova, Yu.V. Zaytseva, and N.A. Cherkunova, "Current directions of improving the policy of energy efficiency in the regions of the Russian Federation (the case of the Volgograd region)," Economy. Business. Informatics, vol. 6, pp. 525-532, 2017. <https://www.internetnauka.com/index.php/journal/article/view/233/29 7>.

[7] Methodology for calculating the values of target indicators in the sphere of energy saving and improving energy efficiency, including the case of comparable conditions. Approved by the Order of the Ministry of Energy of the Russian Federation of June 30, 2014 No. 399, <http://base.garant.ru/70709922/ 